Check for updates

Delhi, India

emailpriyanka@gmail.com

Cite this as: BMJ2020;370:m2859 http://dx.doi.org/10.1136/bmj.m2859 Published: 17 July 2020
COVID-19

\section{What counts as a covid-19 death?}

\section{One of the many difficulties of the pandemic is accurately recording covid-19 deaths. As countries all over the world struggle for consistency, Priyanka Pulla reports on confusion in India}

\section{Priyanka Pulla freelance journalist}

Samar (name changed), 36, is furious at those who run his city. In June, when Suresh, his 38 year old brother, fell sick with symptoms of covid-19, the family struggled to get him treated at any hospital in Bhopal, despite it being the capital of the central Indian state of Madhya Pradesh.

By the time Suresh reached the government run Hamidia Hospital, it was too late. But the family faced another heartbreak-the hospital told them that because Suresh was suspected to have died from covid-19, they couldn't take his body home because of the risk of infection. Instead, it would be taken straight to a crematorium. The family followed the hearse and watched the cremation from a distance.

A few days later, Samar learnt that the city administration hadn't recorded Suresh's death as being from covid-19. This fact makes him furious. "They made us run from pillar to post, and then they didn't even record his death," he told The BMJ.

Suresh's story is not an isolated one. "This is happening a lot," says Rachna Dhingra, a health activist who helped uncover the fact of Suresh's unreported death by scouring through the daily government record of covid-19 fatalities. Towards the end of June, three of Bhopal's crematoriums and burial grounds revealed that they had handled 180 bodies as per covid-19 protocols. And yet, at the time, the city had reported only 91 deaths from the virus.

Faiz Ahmed Kidwai, principal secretary of Madhya Pradesh's Directorate of Health Services, said the state's crematoriums and burial grounds were using covid-19 handling protocols not just for deaths among patients confirmed to have the viral infection, but also for "suspected deaths" in which a patient shows covid-19 symptoms but diagnostic tests have either not been carried out or have returned a negative result. Since it was unclear whether these deaths were from covid-19, Kidwai said, they weren't recorded by the state.

Suresh's death fell in the "suspected" category. When samples from his body were analysed post-mortem, using a test called CBNAAT which checks for viral genetic material, the result was negative for the SARS-COV-2 virus.

But not recording suspected deaths flies in the face of guidelines from India's apex medical research agency, the Indian Council for Medical Research (ICMR). ${ }^{1}$ These are broadly based on World Health Organization's guidelines for the certification of covid-19 deaths. ${ }^{2}$ Because laboratory testing is so limited in India (8.55 tests per thousand people at the time of writing), and methods such as reverse transcription polymerase chain reaction, which also looks for the genetic signature of the virus, and CBNAAT return false negatives, the ICMR recommends that all suspected covid-19 deaths be reported as being from covid-19.

Few Indian cities are doing this, however, partly because doctors are wary of inflating death numbers. Simmi Dube, an internal medicine specialist at Bhopal's Hamidia Hospital, told The BMJ that many patients with covid-19 symptoms could be ill from other causes, such as influenza. Classifying their deaths as covid-19 when test results were negative would wrongly increase mortality numbers and spread panic in an environment where fear was already pervasive, she argued.

As India becomes the country third worst hit by covid-19, with over 900 ooo cases to date, stories about unreported deaths are rising across the country. The governments of multiple cities, including Chennai, Delhi, Hyderabad, Mumbai, and Vadodara, have been accused of hiding covid-19 deaths. This undercounting is often deliberate and fuelled by the political need for state governments to portray success in their outbreak containment efforts, says $\mathrm{T}$ Sundarraman, a health systems researcher based in Puducherry. It's a big problem, he says, because suppressing mortality data "lowers the degree of caution among people.”

The Indian central health ministry has frequently cited these low mortality rates as evidence that its outbreak control measures have been effective. With 18 covid-19 deaths per million people at the time of writing, India does seem to be doing dramatically better than other badly hit countries like the US (420 deaths per million) and Brazil (349 deaths per million). While some of this could be explained by says that if the undercounting of deaths was accounted for, Indian mortality numbers would definitely rise.

\section{Comorbidities}

The non-reporting of suspected covid-19 deaths is not the only problem plaguing Indian statistics. Another problem is doctors attributing covid-19 deaths to complications from other health conditions patients had when they contracted the virus, such as chronic hypertension, diabetes, or cancer, which make people more vulnerable to the effects of the virus. India's relatively younger population, Sundarraman 
But this doesn't mean that the death is from the comorbidity, several experts say. While there may be situations where a person with covid-19 dies from another cause-with the virus a mere bystander-these situations are not common. Prabhat Jha, an epidemiologist at Canada's University of Toronto who is conducting the Million Death Study into the causes of premature deaths in India, says the probability of someone asymptomatic getting a test, testing positive, but then dying in a car accident, for example, is low.

It could also happen that a person with confirmed SARS-COV-2 infection has a myocardial infarction from underlying health conditions unrelated to the virus. Given these exceptional circumstances, WHO and ICMR guidelines allow doctors certifying such deaths to judge whether the virus was the primary cause or not. Yet, the guidelines clearly say that even deaths where the primary cause wasn't covid-19 must be reported as covid-19 deaths.

The rationale for this is that medical researchers are still discovering new ways in which covid-19 can manifest. While the virus was initially believed to kill mainly through respiratory complications like pneumonia, researchers now believe it can fatally damage other organs too. For instance, in May, doctors at New York's Mt Sinai Hospital reported that even in patients with none of the common symptoms like cough and breathlessness, the virus could trigger clots in blood vessels, leading to strokes. ${ }^{3}$ Asymptomatic people can also suffer lung damage, according to a study by scientists from China's Wuhan University. ${ }^{4}$ Other studies show that the virus can inflict serious harm to the kidneys. ${ }^{5}$

For these reasons, a certifying doctor who is unaware of atypical covid-19 symptoms may not certify some deaths correctly. "We're learning that covid-19, particularly in older people, kills in various ways-including heart attack, sudden blood clots, and kidney failure-not just pneumonia. It is prudent, therefore, to define all deaths with any mention of covid-19 anywhere on the death certificate as covid-19-attributable,” says Jha.

\section{Death audit committees}

But many doctors across India seem unaware of this advice. Most states have appointed "death audit committees," panels of doctors who evaluate every covid-19 related death, along with the clinical symptoms and laboratory reports. While the mandate of these committees is to suggest improvements in the clinical management of patients, they also class deaths as either primarily from covid-19 or where the virus is a bystander.

And not all death audit committees are reporting the latter, contrary to ICMR guidelines. For instance, in Vadodara, a major city in the west Indian state of Gujarat, death audit committees attributed nearly $75 \%$ of deaths in covid-19 positive cases to other causes such as complications from diabetes or following organ transplants, said Devesh Patel, the medical officer of health at the city's municipal corporation. He said that none of these deaths were reported in the state's numbers. As a result, the city's reported deaths have only grown from 57 to 60 in the past month, even though the number of cases has more than tripled to 3219.

Such stories are emerging from almost every badly affected Indian city. In May, New Delhi's municipal corporation revealed in a press conference that the city's crematoriums and burial grounds had handled almost double the official number of covid-19. The city's largest government hospital, the Safdarjung Hospital, had reportedly disclosed only a fraction of covid-19 deaths, excluding those attributed to comorbidities.
Eventually, the city government added over 400 deaths to its official toll in June. But Jai Prakash, a member of the North Delhi Municipal Corporation, claims that the Delhi government is continuing to hide the scale of the epidemic. The BMJ asked Ashok Kumar, the head of New Delhi's death audit committee, for comment but has yet to receive a reply.

Large mismatches between citywide death numbers and numbers recorded at individual hospitals have also been reported from Mumbai and Chennai. Meanwhile, a group of health activists called Doctors for Seva in Hyderabad have accused the state of hiding deaths by not testing enough people, and not counting deaths even among covid-19 confirmed patients.

In Bhopal, Samar continues to struggle with his brother's death. The city government's restrictions on cremation practices meant that his family couldn't even say a proper goodbye to Suresh-they only had a moment to see his face one last time. Meanwhile, friends avoided coming to their home for days when they learnt that Suresh had died from suspected covid-19. "If my brother didn't have covid-19, what did they harass us for?” Samar asks.

Competing interests: I have read and understood BMJ policy on declaration of interests and have no relevant interests to declare.

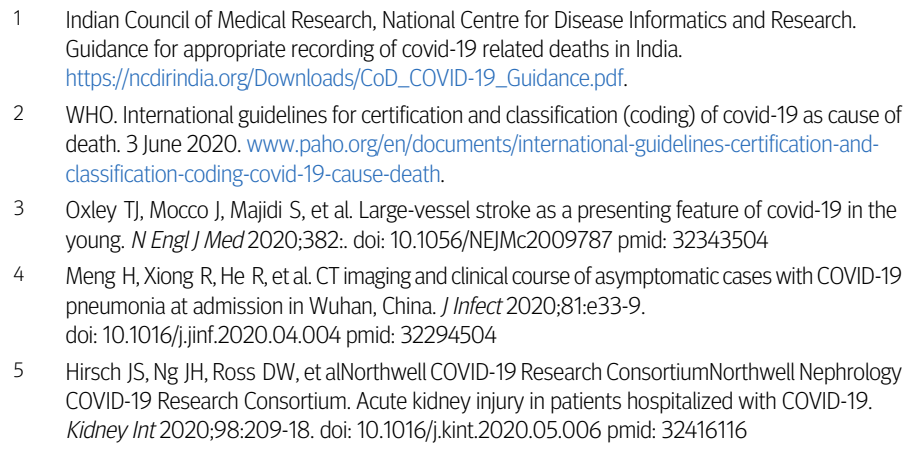

2 WHO. International guidelines for certification and classification (coding) of covid-19 as cause of death. 3 June 2020. www.paho.org/en/documents/international-guidelines-certification-and classification-coding-covid-19-cause-death.

3 Oxley TJ, Mocco J, Majidi S, et al. Large-vessel stroke as a presenting feature of covid-19 in the young. N Engl J Med 2020;382:. doi: 10.1056/NEJMc2009787 pmid: 32343504

4 Meng $\mathrm{H}$, Xiong R, He R, et al. CT imaging and clinical course of asymptomatic cases with COVID-19 pneumonia at admission in Wuhan, China. J Infect 2020;81:e33-9. doi: 10.1016/j.jinf.2020.04.004 pmid: 32294504

5 Hirsch JS, Ng JH, Ross DW, et alNorthwell COVID-19 Research ConsortiumNorthwell Nephrology COVID-19 Research Consortium. Acute kidney injury in patients hospitalized with COVID-19. Kidney Int 2020;98:209-18. doi: 10.1016/j.kint.2020.05.006 pmid: 32416116

This article is made freely available for use in accordance with BMJ's website terms and conditions for the duration of the covid-19 pandemic or until otherwise determined by BMJ. You may use, download and print the article for any lawful, non-commercial purpose (including text and data mining) provided that all copyright notices and trade marks are retained. 